\title{
OPTIMALISASI PENGELOLAAN LAHAN DALAM MENINGKATKAN PRODUKSI JAGUNG, SEBAGAI UPAYA PENINGKATAN PENDAPATAN PETANI DESA BOJONGSANA KABUPATEN TEGAL
}

\author{
Sari Wiyanti \\ Fakutlas Ekonomi \\ Universitas Pancasakti Tegal
}

\begin{abstract}
ABSTRAK
The study was conducted in Bojongsana village, Suradadi Subdistrict, Tegal Regency from April to August 2018 to optimize land in increasing corn production, as an effort to increase the income of farmers in Bojongsana village, Tegal Regency. The population in this study were corn growers. The data used in this study are primary data obtained through direct interviews with respondents. While secondary data was obtained from the office of the Bojongsana Village Chief and the Suradadi Agriculture Service Office in Tegal Regency. Sampling using Purposive sampling, namely samples are farmers who have the ability and experience in planting corn according to the purpose of this study. Data and information collected then processed and discussed qualitatively descriptive. The results show that by optimizing the land after the rice harvest, which is utilized for corn production with the strategy of the SWOT analysis can increase farmers' income. To meet market demand for corn, there needs to be a sustainable development of corn production in Bojongsana village, Suradadi District, Tegal Regency.
\end{abstract}

Keyword: SWOT Analysis

\section{PENDAHULUAN}

Untuk membangun suatu wilayah diperlukan strategi yang tepat dengan menggali potensi atau keunggulan yang dimiliki suatu daerah. Sektor pertanian memiliki peran yang strategis dalam pembangunan perekonomian nasional, andil di dalamnya mengentaskan kemiskinan, menyediakan lapangan kerja.

Menurut Sadono Sukirno (2013) Tingkat produksi sektor pertanian sangat dipengaruhi oleh faktor-faktor yang berada diluar kemampuan petani untuk mengendalikannya. Perubahan musim terutama dipengaruhi oleh keadaan cuaca, iklim dan faktor-faktor alamiah yang lain seperti banjir, hujan yang terlalu banyak atau kemarau yang terlalu panjang. Disamping itu serangan hama tanaman dan binatang pengganggu, misalnya serangan tikus dan burung ke tanaman padi juga dapat menimbulkan pengaruh yang sangat penting terhadap perubahan produksi hasil pertanian.

Tiga tahun berturut turut para petani desa Bojongsana gagal panen baik penanaman padi, bawang ataupun sayursayuran maupun tanaman palawija. Biaya yang dikeluarkan selama masa tanam sampai panen lebih besar dari produksi yang dihasilkan. Musim ke- 
marau yang panjang menyebabkan kurangnya air untuk mengairi sawah, ini penyebab utama petani penggarap enggan untuk bertani. Faktor lainnya yang menjadi penyebab gagalnya panen yang dialami petani, diantaranya serangan hama, mahalnya pestisida pembasmi hama, mahalnya harga varietas bibit unggul dan pupuk, serta biaya tenaga kerja harian yang mahal.

Di lihat dari letak geografisnya tanah sawah di desa Bojongsana dapat dijadikan sasaran budidaya produksi jagung, Lahan yang tersedia dapat di optimalkan dalam pengembangan budidaya jagung. Pola tanam dan kebiasaan petani dalam menanam jagung yang kurang intensif sehingga hasil produksi jagung sangat rendah. Untuk mencapai mutu dan produktivitas perlunya upaya pengembangan produksi jagung yang kompetitif .

Menurut Rangkuti Freddy 2014, Pentingnya perencanaan strategis (strategic planner) dalam menganalisis faktor-faktor strategis dalam pengelolaan usaha (seperti kekuatan, peluang, kelemahan dan ancaman) yang sesuai dengan kondisi saat ini. Strategi manajemen dengan analisis SWOT dalam rangka merumuskan strategi pengembangan produksi jagung sebagai upaya peningkatan pendapatan para petani, dengan optimalisasi pengelolaan lahan yang tersedia untuk meningkatkan produktivitas hasil jagung dengan strategi terobosan yang sesuai dengan kondisi alam.

\section{TINJAUAN PUSTAKA}

Pengembangan produksi jagung dapat meningkatkan pendapatan dan kesejahteraan petani, memperluas lapangan kerja, dan kesempatan berusaha, meningkatkan produksi untuk memenuhi kebutuhan pangan dan non pangan di dalam negeri, serta mengurang impor jagung.

Menurut Soekartawi, 1999 banyak kendala yang dihadapi petani dalam proses produksi pertanian untuk mencapai produksi yang tinggi, kendala yang sering ditemui diklasifikasikan sebagai berikut :

Kendala yang mempengaruhi yield gap I yang terdiri dari variabel di luar kemampuan manusia, sehingga sulit menggunakan transfer teknologi yang disebabkan karena perbedaan agroklimat dan teknologi sulit diadopsi)

Kendala yang mempengaruhi yield gap II yang terdiri dari variabel teknis biologis (bibit, puppuk, obat-obatan, dan lainlain) dan variabel ekonomi (harga, resiko, ketidakpastian, kredit, adat dan lain-lainnya)

Tingkat adopsi teknologi yang digunakan dapat mempengaruhi tingkat produktivitas. Apabila petani mengadopsi apa yang disarakan oleh penyuluh petanian, penggunaan teknologi pastinya akan meningkatkan produksi jagungnya. Petani harus mulai beralih dari cara tradisional kepada penggunaan teknologi yang lebih maju dalam budidaya jagung.

Sektor pertanian di Indonesia masih dipengaruhi oleh iklim, curah hujan, dan ketersediaan air irigasi. Sehingga sektor pertanian perlu dikelola dengan baik, dibutuhkan juga strategi manajemen dalam sistem pengelolaannya.

Strategic management model meliputi environmental scanning, strategi formulasi, strategi implementasi, dan strategi evaluasi dan kontrol (David Hunger, Wheelen, 2008:8). Environmental scanning artinya memonitor, mengevaluasi dan menyebarkan informasi tentang keadaan eksternal dan 
internal perusahaan kepada orang-orang yang pegang posisi dalam perusahaan. Untuk melakukan environmental scanning ini biasanya digunakan analisis SWOT (Strenghts, Weakness, Opportunity and Threats).

Rangkuti Freddy (2014) mendefinisikan Analisis SWOT adalah identifikasi bebagai faktor secara sistematis untuk merumuskan strategi perusahaan. Analisis ini berdasarkan dengan memaksimalka (Strengths), mencapai peluang (Opportunities), dengan meminimalkan kelemahan (Weaknesses) dan ancaman (Threats). Dengan analisis SWOT dapat membandingkan antara faktor Internal Menurut Rangkuti Freddy 2014, yaitu kekuatan (Strength) dan kelemahan (Weaknesses) dengan faktor Eksternal yaitu peluang (opportunities) dan ancaman (threaths). Matriks SWOT menggambarkan secara jelas bagaimana peluang dan ancaman eksternal yang dihadapi, disesuaikan dengan kekuatan dan kelemahan yang dimiliki (Freddy Rangkuti, 2014). Diagram matrik SWOT dapat dilihat pada tabel 1 dibawah ini :

Tabel 1. Diagram Matrik Analisis SWOT.

\begin{tabular}{|c|c|c|}
\hline $\begin{array}{l}\text { Internal Factor Evaluation } \\
\text { (IFAS) / Eksternal Factor } \\
\text { Evaluation (EFAS) }\end{array}$ & STRENGTHS (S) & WEAKNESSES (W) \\
\hline & $\underline{\text { Strategi SO }}$ & Strategi Wo \\
\hline \multirow[t]{2}{*}{ OPPORTUNITIES } & $\begin{array}{l}\text { Menciptakan strategi yang } \\
\text { menggunakan kekuatan untuk } \\
\text { memenfaatkan peluang }\end{array}$ & $\begin{array}{l}\text { Menciptakan strategi yang } \\
\text { meminimalkan kelemahan } \\
\text { untuk memanfaatkan } \\
\text { peluang }\end{array}$ \\
\hline & $\underline{\text { Strategi ST }}$ & Strategi WT \\
\hline THREATHS (T) & $\begin{array}{l}\text { Menciptakan strategi yang } \\
\text { menggunakan kekuatan untuk } \\
\text { mengatasi ancaman }\end{array}$ & $\begin{array}{l}\text { Menciptakan strategi yang } \\
\text { meminimalkan kelemahan } \\
\text { dan menghindari ancaman }\end{array}$ \\
\hline
\end{tabular}

Matrik SWOT diatas merupakan alat pencocokan yang penting untuk membantu dalam mengembangkan empat tipe strategi yaitu Strategi SO (Strength, Opportunities), Strategi WO (Weaknesses-Opportunities), Strategi ST (Stregth-Threats) dan Strategi WT (Weaknesses-Threats). Sehingga terdapat 8 langkah menyusun matrik SWOT, yaitu:
Menentukan kekuatan internal

Menentukan kelemahan internal

Menentukan peluang eksternal

Menentukan ancaman eksternal

Mencocokan kekuatan internal dengan peluang ekternal dan mencatat resultan strategi $\mathrm{SO}$ dalam sel yang tepat

Mencocokan kelemahan internal dengan peluang eksternal dan mencatat resultan strategi WO dalam sel yang tepat

Mencocokan kekuatan internal dengan ancaman eksternal dan mencatat resultan strategi ST dalam sel yang tepat

Mencocokan kelemahan internal dengan ancaman eksternal dan mencatat strategi WT dalam sel yang tepat.

\section{HIPOTESIS PENELITIAN}

Dari uraian permasalahan yang ada maka hipotesis yang diajukan adalah Menganalisa kekuatan/Strengths desa Bojongsana untuk produksi Jagung

Menganalisa kelemahan/Weaknesses petani jagung dalam memproduksi jagung

Menganalisa peluang/ opportunities terhadap produksi jagung yang dapat dicapai

Menganalisa Ancaman/Threath terhadap produksi jagung

Menganalisa strategi SWOT dalam produksi jagung dapat meningkatkan pendapatan petani di desa Bojongsana Kabupaten Tegal

\section{METODE PENELITIAN}

Penelitian ini adalah jenis penelitian deskriptif yang bersifat kualitatif dari studi kasus dimana pengumpulan data dilakukan dengan survey dan observasi. 
Obyek penelitian ini adalah petani di desa Bojongsana Kabupaten Tegal, dimana penelitian dilakukan di selama 4 bulan.

Teknik pengambilan sampel menggunakan Purposive sampling yaitu pengambilan sampel dengan menetapkan ciri sesuai dengan tujuan. (Sugiyono, 2003 74-78). Sampel yang diambil adalah petani Bojongsana yang mempunyai pengalaman dalam menanam jagung.

Data yang digunakan dalam penelitian ini adalah data primer dan data sekunder. Data primer diperoleh dari wawancara dengan petani, kelompok tani, dan mitra tani. Observasi dan survey lapangan bertujuan untuk memperoleh informasi mengenai lahan yang akan dilakukan penelitian ini. Data sekunder dalam penelitian ini diperoleh dari Kantor Kepala Desa Bojongsana Kabupaten Tegal dan Dinas Pertanian Kecamatan Suradadi, Kabupaten Tegal terkait mulai pengumpulan data dan informasi mengenai kondisi geografis, potensi desa, produksi, penggunaan teknologi dalam produksi jagung.

Analisa data dengan analisis SWOT, menurut Rangkuti Freddy (2014) mendefinisikan Analisis SWOT adalah identifikasi bebagai faktor secara sistematis untuk merumuskan strategi perusahaan. Analisis ini berdasarkan dengan memaksimalkan kekuatan (Strengths), mencapai peluang (Opportunities), dengan meminimalkan kelemahan (Weaknesses) dan ancaman (Threats). Pentingnya perencanaan strategis (strategic planner) dalam menganalisis faktor-faktor strategis dalam pengelolaan usaha (seperti kekuatan, peluang, kelemahan dan ancaman) yang sesuai dengan kondisi saat ini.

Serta mengetahui strategi manajemen analisis SWOT dalam pengaruhnya terhadap optimalisasi pengelolaan lahan untuk meningkatkan produksi jagung, sebagai upaya peningkatkan pendapatan petani di desa Bojongsana Kabupaten Tegal.

\section{PEMBAHASAN DAN HASIL}

Desa Bojongsana secara geografis terletak dipesisir pantai utara, tepatnya bagian timur wilayah Kecamatan Suradadi. Luas Wilayah keseluruhan Desa Bojongsana Kabupaten tegal \pm 430,8353 hektar, dimana luas area pertanian secara keseluruhan $\pm 369,459$ hektar dengan area pertanian yang produktif hanya \pm 218 hektar . Desa Bojongsana Kabupaten Tegal dengan jumlah penduduk 4.757 jiwa, dengan pendidikan yang berbeda beda, dapat dilihat pada tabel 2 dibawah ini :

Tabel 2. Pendidikan masyarakat desa Bojongsana

\begin{tabular}{clc}
\hline No & \multicolumn{1}{c}{ Pendidikan } & Jumlah \\
\hline 1 & SD & 1.071 Orang \\
2 & SMP & 849 Orang \\
3 & SMA & 701 Orang \\
4 & S1/S2 & 47 Orang \\
5 & Tidak/Belum sekolah & 2.089 Orang \\
\hline
\end{tabular}

Sumber : Kelurahan Desa Bojongsana.

Penelitian selama 5 bulan mulai April sampai dengan bulan Agustus 2018, melalui survey langsung dan pendampingan dilapangan dan melakukan tanya jawab dengan petani jagung dari pendapatannya petani ratarata Rp. 500.000,00 per bulan. Mahalnya biaya sewa tanah sawah pertahun $\mathrm{Rp}$. 4.500.000 seluas $7000 \mathrm{mtr}^{2} / 1$ bau, dengan mengoptimalkan lahan untuk produksi jagung setelah panen padi, dilakukan pada baru dilakukan pada tahun 2018 diharapkan dapat menambah pendapatan petani.

Peninjauan daerah tempat diadakannya penelitian dan melakukan pendampingan diperoleh informasi faktor internal (kekuatan dan kelemahan) 
dan faktor eksternal (peluang dan ancaman) selama produksi jagung di Desa Bojongsana Kabupaten Tegal. Berikut informasi yang didapatkan dari hasil wawancara dengan Dinas Pertanian Suradadi dan petani jagung Desa Bojongsana Kabupaten Tegal, sebagai berikut

Beberapa kekuatan pada produksi jagung didaerah tersebut

Tersedianya lahan yang ideal untuk produksi jagung

Pengalaman petani dalam menanam dan memproduksi jagung

Ketersediaan bibit jagung berkualitas yang berpotensi hasil tinggi

Ketersediaan tenaga kerja petani, berdasarkan data penduduk daerah tersebut

Ketersediaan kebutuhan produksi pertanian di daerah tersebut

Beberapa kelemahan pada produksi jagung didaerah tersebut

Produktivitas rendah

Biaya produksi jagung yang tinggi

Minimnya ketersediaan pengairan ke lahan petani

Pengairan ke sawah masih mengandalkan air hujan

Lahan pertanian yang semakin sempit

Keraguan terhadap pemasaran hasil produksi jagung

Beberapa peluang pada produksi jagung di desa Bojongsana Kabupaten Tegal

Permintaan jagung saat ini sangat tinggi, sementara pe- tani belum mampu memenuhi permintaan tersebut

Kualitas produksi jagung yang baik, dimana hasil produksi jagung bebas dari serangan hama penyakit

Banyaknya produksi jagung yang rutin dilakukan, untuk memenuhi permintaan jagung yang tinggi.

Beberapa ancaman dalam produksi jagung di desa Bojongsana Kabupaten Tegal

Harga jagung yang fluktuatif dipasaran dipengaruhi oleh berbagai faktor seperti masa panen maka harga jagung akan turun, termasuk sarana transportasi

Tidak adanya perusahan/ pengepul yang menampung hasil jagung

Masih kurangnya lembaga yang mendukung usaha produksi jagung, seperti lembaga keuangan dan perusahaan yang mendukung modal petani, lembaga penyuluhan dan tidak adanya kelompok tani yang aktif.

Gagalnya penggunaan predator untuk mengatasi hama tikus untuk melindungi hasil produksi jagung

Iklim dan cuaca yang tidak menentu

Sarana transportasi yang tersedia dan akses jalan daerah penelitian akan berperngaruh pada harga jual jagung. Harga jagung pada tempat yang mudah dijangkau oleh pengepul akan lebih tinggi daripada tempat yang sulit dijangkau. 
Tabel 3. Matriks SWOT Pengembangan Produksi Jagung di Daerah Penelitian

\begin{tabular}{|c|c|c|}
\hline Eksternal & $\begin{array}{l}\text { STRENGHTS (S) } \\
\text { - } \text { Tersedianya lahan } \\
\text { - } \begin{array}{l}\text { Pengalaman petani dalam } \\
\text { budidaya jagung }\end{array} \\
\text { - } \text { Tersedianya bibit berkualitas } \\
\text { - } \quad \text { Tenaga kerja tersedia } \\
\text { - Sarana/ kebutuhan produksi } \\
\text { tersedia } \\
\text { - Kemudahan dalam menjual } \\
\text { hasil produksi Jagung }\end{array}$ & $\begin{array}{l}\text { WEAKNESS }(\mathrm{W}) \\
\text { - Produksi jagung masih } \\
\text { rendah } \\
\text { - } \text { Biaya produksi tinggi } \\
\text { - Minimnya ketersediaan air } \\
\text { untuk pengairan } \\
\text { - Pengairan masih } \\
\text { mengandalkan air hujan } \\
\text { - Keraguan pemasaran jagung }\end{array}$ \\
\hline $\begin{array}{l}\text { OPPORTUNITIES }(\mathrm{O}) \\
\text { - } \begin{array}{l}\text { Permintaan Jagung yang } \\
\text { tinggi }\end{array} \\
\text { - } \begin{array}{l}\text { Kualitas jagung yang baik } \\
\text { - }\end{array} \\
\begin{array}{l}\text { Rutinitas petani dalam } \\
\text { produksi jagung untuk } \\
\text { pemenuhan permintaan }\end{array}\end{array}$ & $\begin{array}{l}\text { STRATEGI SO } \\
\text { - Meningkatkan produksi dan } \\
\text { kualitas sesuai permintaan } \\
\text { pasar (S1, S2, S4, O1, O2, } \\
\text { O3) } \\
\text { - Mengoptimalkan produksi } \\
\text { jagung menggunakan } \\
\text { teknologi (S1, S3, S4, O2, } \\
\text { O3) }\end{array}$ & $\begin{array}{l}\text { STRATEGI WO } \\
\text { - Mengumpulkan informasi } \\
\text { guna meningkatkan produksi } \\
\text { jagung (W1,W2, W3, W5, } \\
\text { O1, O2) } \\
\text { - Meningkatkan pengelolaan } \\
\text { dan pemeliharaan yang } \\
\text { efektif (W1, W2, W3, O2, } \\
\text { O3) }\end{array}$ \\
\hline 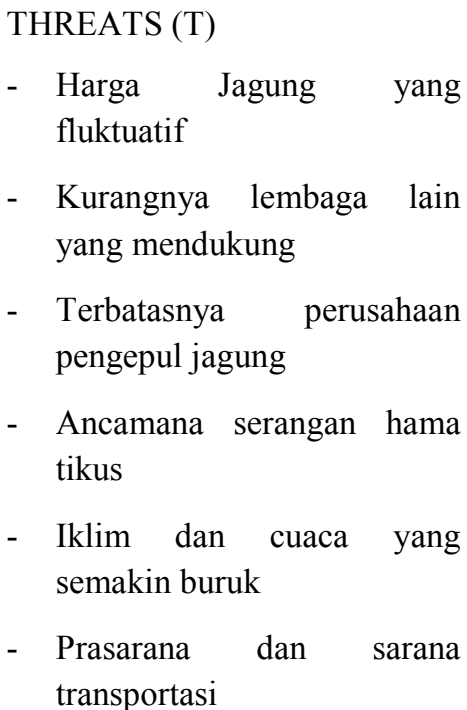 & 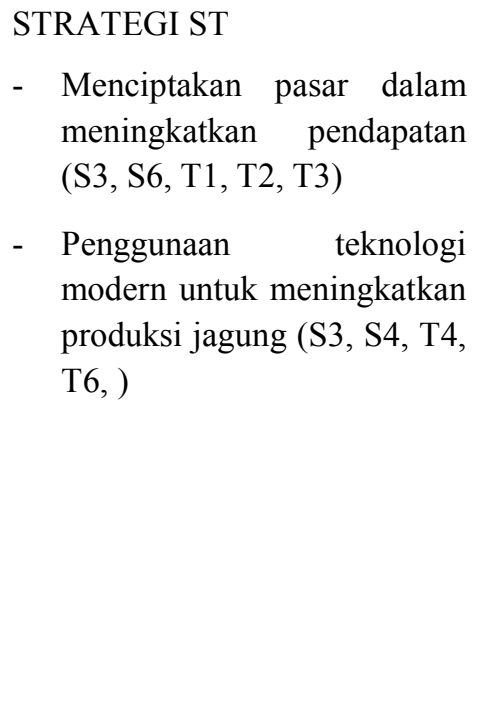 & $\begin{array}{l}\text { STRATEGI WT } \\
\text { - } \text { Mengaktifkan kelompok tani } \\
\text { untuk meningkatkan SDM } \\
\text { didaerah penelitian (W5, T3) }\end{array}$ \\
\hline
\end{tabular}

Hasil dari wawancara dengan petani desa Bojongsana Kabupaten Tegal, bahwa produksi padi hanya dapat dilakukan pada saat musim penghujan. Tanaman padi sangat membutuhkan air yang sangat banyak dari awal pengolahan tanah sampai panen tiba.

Desa Bojongsana yang hanya mengandalkan air selain dan air sungai yang melimpah pada musim penghujan. Hasil produksi padi akan maksimal apabila kebutuhan air terpenuhi. Berikut hasil wawancara tentang pendapatan petani dari produksi padi, digambarkan pada sebagai berikut : 


\section{PENDAPATAN HASIL PRODUKSI PADI}

HASIL PRODUKSI PADI SELUAS $\pm 7000 \mathrm{M}^{2} \quad 4.500 \mathrm{Kg} \times \mathrm{Rp} .5000 / \mathrm{Kg} \quad \mathrm{Rp} .22 .500 .000$ BIAYA PRODUKSI PADI

Persiapan lahan 1 bau (7.000 M)

Obat Pembasmi rumput/roundup Rp. 260.000

Tenaga kerja 1 org

Rp. 100.000

Biaya traktor

Rp. 1.100 .000

Bibit padi 5 bksx 5 kgx Rp. 70.000

Rp. 350.000

Biaya tandur 8 Org x Rp. 100.000

Rp. 800.000

$$
\text { Jumlah }
$$

Rp. $2.610 .000 \quad$ Rp. 19.890 .000

\section{Pemupukan pertama umur padi 12 hari}

Campuran pupuk Urea, ponska, SP 16

Rp. 660.000

Obat rumput sunatra, convey, adjus

Rp. 360.000

Tenaga kerja Rp. 80.000

Rp. 80.000

$$
\text { Jumlah }
$$

$\begin{array}{lll}\text { Rp. } 1.100 .000 & \text { Rp. } 18.790 .000\end{array}$

Perbaikan saluran air

$\begin{array}{ll}\text { Rp. } 300.000 & \text { Rp. } 18.490 .000\end{array}$

\section{Pemupukan umur padi 25 hari}

Campuran pupuk urea, ponska, SP 16

Rp. 660.000

Obat rumput sunatra, convey, adjus

Rp. 360.000

Tenaga kerja Rp.80.000

Rp. 80.000

$$
\text { Jumlah }
$$

$\begin{array}{ll}\text { Rp. } 1.100 .000 & \text { Rp. } 17.390 .000\end{array}$

Pemupukan \& penyemprotan ulat $\&$ wereng umur padi $45 \mathrm{hr}$

Campuran pupuk urea, ponska, SP $16 \quad$ Rp. 660.000

Campuran pestisida Antrakol dan resotin Rp. 143.000

Tenaga Kerja 1 hari Rp. 100.000 Jumlah

Rp. $903.000 \quad$ Rp. 16.487 .000

Pembasmian ulat dan wereng umur padi 60 hari
Campuran pestisida Antrakol, Rp. 143.000
Resotin/sumo
Campuran matador dan resotin
Rp. 200.000
Tenaga kerja
Rp. $\quad 100.000$

Jumlah

$\begin{array}{ll}\text { Rp. } 443.000 & \text { Rp. } 16.044 .000\end{array}$ 
Pembasmian ulat dan wereng umur 66 padi hari

Campuran pestisida Antrakol, Resotin/ Rp. 143.000 sumo

Campuran matador dan resotin

Rp. 200.000

Tenaga kerja

Rp. 100.000

Jumlah

Rp. $443.000 \quad$ Rp. 15.601 .000

Pembasmian ulat dan wereng umur padi 72 hari

Campuran pestisida Antrakol, Resotin/ Rp. 143.000 sumo

Campuran matador dan resotin

Rp. 200.000

Tenaga kerja

Rp. 100.000

Jumlah

Rp. $443.000 \quad$ Rp. 15.158 .000

Pembasmian ulat dan wereng umur padi 78 hari

Campuran pestisida Antrakol, Resotin/ Rp. 143.000 sumo

Campuran matador dan resotin

Rp. 200.000

Tenaga kerja

Rp. 100.000

Jumlah

Rp. $443.000 \quad$ Rp. 14.715 .000

Pembasmian ulat dan wereng umur 84 hari

Campuran pestisida Antrakol, Rp. 143.000

Resotin/sumo

Campuran matador dan resotin

Rp. 200.000

Tenaga kerja

Rp. 100.000

Jumlah

Rp. $443.000 \quad$ Rp. 14.272 .000

Pembasmian ulat dan wereng umur 90 hari

Campuran pestisida Antrakol, Rp. 143.000

Resotin/sumo

Campuran matador dan resotin

Rp. 200.000

Tenaga kerja

Rp. 100.000

Jumlah

Rp. $443.000 \quad$ Rp.13.829.000

Biaya panen : Sewa Alat pemotong padi

Rp. $2.400 .000 \quad$ Rp.11.429.000

Pendapatan Kotor Petani dari produksi padi / thn

Rp.11.429.000 
Dapat dihitung pendapatan petani dari produksi padi dikurangi biaya sewa tanah pertahun, Rp. 11.429.000 - Rp. $4.500 .000=$ Rp. 6.929.000, maka akan terlihat penghasilan petani Rp. yaitu Rp. 6.929.000; 12 bulan $=$ Rp. 577.417 per bulan.

Untuk menambah penghasilan yang diperoleh petani Rp. 577.417 per bulan dengan menggunakan strategi pengolahan lahan, memanfaatkan peluang yang ada dengan mengoptimalkan tanah dan memanfaatkan air yang tersedia setelah panen padi untuk penanaman jagung.

Dari hasil penelitian dan pendampingan di lapangan, ada peningkatan pendapatan pertanian dengan memanfaatkan lahan setelah panen padi. Walaupun biaya yang dikeluarkan petani pada proses produksi jagung masih tinggi tetapi masih ada keuntungan yang diperoleh petani. Perhitungan sederhana pendapatan petani produksi jagung dapat dilihat

\section{PENDAPATAN HASIL PRODUKSI JAGUNG}

HASIL PRODUKSI JAGUNG LAHAN $7000 \mathbf{~ m}^{2}(\mathbf{1}$ bau $)=\mathbf{3 . 5 0 0 ~ k g ~ p o c e l a n ~} \quad$ Rp. 14.525 .000 X Rp. 4.150/ kg

\section{BIAYA}

\section{Persiapan Lahan}

Obat Pembasmi rumput/roundup

Rp. 130.000

Tenaga kerja 1 hari

$$
\begin{array}{lll}
\text { Rp. } 100.000 & \text { Rp. } 230.000 & \text { Rp. } 14.295 .000 \\
& \text { Rp. } 1.200 .000 & \text { Rp. 13.095.000 }
\end{array}
$$

Pembuatan palir atau aliran air

\section{Penanaman benih jagung}

Benih Jagung Rp. 110.000x 16 bks

Rp. 1.760 .000

Obat Anti bulai/marsal Rp. 35.000/btl x 4 Rp. 140.000 btl

Tenaga kerja 8 orgX $1 / 2$ hr X Rp. 80.000

Rp. 320.000

Rp. 2.200 .000

Rp. 10.895 .000

\section{Pemupukan dan pemeliharaan jagung umur 15 hari}

Campuran pupuk Urea, ponska, SP 16

Rp. 660.000

Campuran pestisida sunatra, convey, Rp. 360.000 adjust

Tenaga kerja 1 org x $1 \mathrm{hr}$

Rp. 80.000

Rp. 1.100 .000

Rp. 9.795 .000

Pemupukan dan pemeliharaan jagung umur 25 hari

Campuran pupuk Urea, ponska, SP 16

Rp. 660.000

Obat Pucuk daun Poradan

Rp. 108.000

Campuran pestisida Antrakol, resotin

Rp. 143.000

Tenaga kerja 1 org x $1 \mathrm{hr}$

Rp. 100.000

Rp. $1.011 .000 \quad$ Rp. 8.784 .000 


\section{Pemupukan dan pemeliharaan jagung umur 45 hari}

Campuran pupuk Urea, ponska, SP 16

Obat Pucuk daun Poradan

Campuran pestisida Antrakol, resotin

Tenaga kerja 1 org x $1 \mathrm{hr}$
Rp. 660.000

Rp. 108.000

Rp. 143.000

Rp. 100.000

Rp. 7.773 .000

\section{Pemupukan dan pemeliharaan jagung umur 60 hari s/d panen}

Obat perbesar buah Sondawa buah, Rp. 1.140.000

Nitrea, ZA

Campuran pestisida Antrakol, resotin

Rp. 143.000

Tenaga kerja 1 org x $1 \mathrm{hr}$

Rp. 100.000

Rp. 1.383 .000

Rp. 6.390 .000

\section{Biaya panen jagung}

Tenaga Kerja 11 org x 1 hr x Rp. 80.000

Rp. 880.000

Ongkos angkut jagung

Rp. 375.000

Rp. 1.255 .000

Rp. 5.135 .000

\section{Pendapatan kotor petani dari produksi jagung}

Rp. 5.135.000

Penghasilan petani kalau hanya menanam padi saja selama satu tahun Rp. 11.429.000, apabila ditambah dengan penghasilan menanam jagung sebesar Rp. 5.135.000 adalah Rp. 16.564.000 dikurangi sewa tanah sebesar Rp. $4.500 .000=$ Rp. 12.064.000/thn : 12 bulan = Rp. 1.005.333/bulan. Ada kenaikan pendapatan pendapatan ratarata perbulan sebesar Rp. 427.916.--

Fluktuasi harga berpengaruh juga pada pendapatan petani. Menurut Sadono Sukirno (2013) bahwa masalah jangka pendek sector pertanian dalam jangka pendek harga hasil - hasil pertanian cenderung mengalami naik turun yang relative besar. Harga boleh mencapai tingkat yang sangat tinggi pada sesuatu masa, sebaliknya mencapai kemrosotan yang sangat buruk pada masa berikutnya.

\section{KESIMPULAN}

Kegiatan pertanian di desa Bojongsana yang masih mengandalkan air pada musim hujan. Sehingga banyak sekali lahan kering yang terbengkalai karena kekurangan air. Lahan dibiarkan terbengkalai setelah panen padi, merupakan keputusan petani daripada merugi apabila dilakukan penanaman kembali.

Penggunaan strategi manajemen dengan analisis SWOT dalam rangka merumuskan strategi pengembangan produksi jagung dalam rangka peningkatan pendapatan para petani, dengan optimalisasi pengelolaan lahan yang tersedia untuk meningkatkan produktivitas hasil jagung dengan strategi terobosan yang sesuai dengan kondisi alam.

Peninjauan daerah tempat diadakannya penelitian dan melakukan pendampingan untuk mengetahui faktor internal (kekuatan dan kelemahan) dan faktor eksternal (peluang dan ancaman) selama produksi jagung di desa Bojongsana Kabupaten Tegal. Untuk mengetahui faktor internal, langkah dalam pengumpulan data yaitu 
Beberapa kekuatan pada produksi jagung di desa Bojongsana Kabupaten Tegal tersebut

Tersedianya lahan yang ideal untuk produksi jagung

Pengalaman petani dalam menanam dan memproduksi jagung

Ketersediaan bibit jagung berkualitas yang berpotensi hasil tinggi

Ketersediaan tenaga kerja petani, berdasarkan data penduduk daerah tersebut

Ketersediaan kebutuhan produksi pertanian di daerah tersebut

Beberapa kelemahan pada produksi jagung didaerah tersebut

Produktivitas rendah

Biaya produksi jagung yang tinggi

Minimnya ketersediaan pengairan ke lahan petani

Pengairan ke sawah masih mengandalkan air hujan

Lahan pertanian yang semakin sempit

Keraguan terhadap pemasaran hasil produksi jagung

Beberapa peluang pada produksi jagung di desa Bojongsana Kabupaten Tegal

Permintaan jagung saat ini sangat tinggi, sementara petani belum mampu memenuhi permintaan tersebut

Kualitas produksi jagung yang baik, dimana hasil produksi jagung bebas dari serangan hama penyakit

Banyaknya produksi jagung yang rutin dilakukan, untuk memenuhi permintaan jagung yang tinggi.
Beberapa ancaman dalam produksi jagung di desa Bojongsana Kabupaten Tegal

Harga jagung yang fluktuatif dipasaran dipengaruhi oleh berbagai faktor seperti masa panen maka harga jagung akan turun, termasuk sarana transportasi

Tidak adanya perusahan/ pengepul yang menampung hasil jagung

Masih kurangnya lembaga yang mendukung usaha produksi jagung, seperti lembaga keuangan dan perusahaan yang mendukung modal petani, lembaga penyuluhan dan tidak adanya kelompok tani yang aktif.

Gagalnya penggunaan predator untuk mengatasi hama tikus untuk melindungi hasil produksi jagung

Iklim dan cuaca yang tidak menentu

Sarana transportasi yang tersedia dan akses jalan daerah penelitian akan berperngaruh pada harga jual jagung. Harga jagung pada tempat yang mudah dijangkau oleh pengepul akan lebih tinggi daripada tempat yang sulit dijangkau.

Dengan menggunakan analisis SWOT dalam optimalisasi lahan terdapat kenaikan pendapatan rata-rata petani setiap bulannya.

\section{Saran}

Dari Fenomena dan hasil dari penelitian maka untuk penelitiian selanjutnya

Memanfaatkan air laut melalui filterisasi untuk pengairan sawah 
Kerjasama dengan perusahaan nasional sebagai penampung hasil panen jagung

Kerjasama petani dengan lembaga keuangan untuk membantu per- modalan petani dalam produksi jagung

Penggunaan teknologi pengusir hama tikus, penggunaan predator sudah tidak efektif.

\section{DAFTAR PUSTAKA}

Ahmad, R.O.(2011), "Strenghts,Weaknesses, Opportunities and Threats(SWOT) analysisfor farming system businesses management: Case of wheat farmers of Shadervan District, Shouhtar Township, Iran"African journal of Business Management Vol. 5 (22)

Baiq, T. R.E \& Awaludin, H. (2015), "Pengaruh Jarak Tanam terhadap Pertumbuhan dan Hasil beberapa Varietas Jagung Hibrida di Kawaasn Pengembangan Jagung Sumbawa”, Balai Pengkajian teknologi Pertanian Nusa Tenggara Barat

Elizabeth, R.(2007), "Role and opportunity of corn and livestock Integration in Affecting Cognitive Intellegent of Poor Farmer in Marginal Land", Seminar Nasional Teknologi Peternakan dan Veteriner 2007

J. David Hunger \& Thomas L Wheelen (2003), Manajemen Strategis, Penerbit Andi Yogyakarta

Nano, P. (2010), Pengembangan Potensi Unggulan Sektor Pertanian, Jurnal Ekonomi dan Studi Pembangunan, Volume 11, Nomor 1, April 2010

Paudel, B., et al. "Yield and Economics of Maize (Zea mays)+ Soybean (Glycin max L. Merril) Intercropping System under Different Tillage Methods", World Journal Agriculture Research 3.2 (2015): 74-77

Buchari, A.(2010), Pengantar Bisnis, ALFABETA, Bandung

Pusat pelatihan pertanian, Badan penyuluhan dan pengembangan SDM pertanian, 2015

Reckleben, Y. (2011), Cultivation of maize - which sowing row distance is needed

Freddy, R. (2014), Analisis SWOT - Teknik Membedah Kasus Bisnis, Gramedia Pustaka Utama

Rhenald, K. (2008), Riset Kualitatif, Penerbit Bentang

Sadono, S. (2013),Teori Pengantar Ekonomi Mikro, Edisi 3 Pt. RajaGrafindo Persada

T.T.Liu, B.G.McConkey, et.al. (2011), Strength, Weaknessness, Opportnities and Threaths Analysis of Bioenergy Production on Marginal Land, Energy Procedia 5 (2100) 2378-2386 Published by Elsevier Ltd. Doi : 10.1016 / j.egypro. 2011.03.409

Tika B, K., Jiban S. \& Buddhi B, A,(2015), Status and prospects of maize research ini Nepal, journal of Maize Research and Development (2015) 1 (1):1-9 DOI:10.5281/zenodo 34284

Twenty L, M. \& Zulfikar, "Potential of Corn Development in Suboptimal Land of Central Kalimantan” Balai Pengkajian Teknologi Pertanian Kalimantan Tengah

Yulmar, J.(2015), "Production System and Potential Development of corn in West Pasaman Districts", Peneliti Bidang Bappeda Provinsi Sumatera Barat, Jurnal Bina Praja/Volume 7 no 3 Edisi September 2015 : 271 - 278 